\title{
HOW DOES LEADERSHIP STYLE INFECT SUBORDINATES' OUTCOMES: THE MEDIATING ROLE OF SUBORDINATES' SELF-CONCEPTS
}

\author{
Lin, Xiaoxia \\ Management School, Guilin University of Aerospace Technology, China
}

\begin{abstract}
The research explores the connection between leadership styles (i.e., authoritarian leadership and benevolent leadership) and subordinate's work results (i.e., job performance, OCB-I and OCB-O) among a sample of people who work in Chinese companies $(\mathrm{N}=185)$. The findings have addressed that leadership styles were indirectly associated with subordinate's performance via their self-concepts. Our study promotes leadership literature by revealing the mechanism of leadership styles on employees' attitudes and behaviors in working place.
\end{abstract}

Key words: authoritarian leadership, benevolent leadership, self-concept

\section{INTRODUCTION}

Preceding leadership theories are mainly generated in the western environment. Scholars indicated that some theories were influential in the western world, whereas they might not function well in some other cultures. Therefore, scholars appealed for localizing leadership theories. Farh and Cheng (2000) proposed benevolent leadership and authoritarian leadership by conducting studies in Chinese corporations [1]. These leadership styles combine fatherly kindness with authority and are common in China. Benevolent leadership and authoritarian leadership are rooted in Confucianism's values. Authoritarian leadership reflects a paternity-like relationship where a father carries lawful authority beyond all family members. Benevolent leadership reflects reciprocity's norms in relationships' Confucian hierarchy.

In the meantime, gender matters in leadership have lately become another study focus. Wang et al. (2013) demonstrated that gender stereotypes influence people's views of leadership effectiveness. It shows that subordinates would negatively evaluate female managers who act with masculine leadership behaviors. Evidence revealed that managers' gender differs the connection between subordinates' work results and leadership behaviors [2]. The findings suggested that more negative effects on subordinates' performance would arise when female leaders had authoritarian leadership than male leaders did. The literature demonstrates that people will assess leadership efficiency through their anticipations of ideal leaders in the light of behaviors and characteristics.

Hogg et al. (2012) suggested the social identity theory of leadership and addressed that the more group prototypical the leaders are, the more positive the assessment is[3]. Group members are categorized by individuals' cognitive prototype, i.e., a set of elements including beliefs, behaviors, etc. The prototype shares ingroup similarities and shows intergroup differences. Hogg \& Reid (2006) found that people tend to exchange distinctions and similarities from who best or poorly represents their group identities [4]. People obtain information about the prototype through this type of communication. People have group-shared beliefs, attitudes, and behaviors while they band themselves with the group. While the leadership styles are congruent to the group's shared prototypes, followers take positive performances.

Individuals' self-concepts may have a substantial influence on the prototypes. Self-concept is defined as the identity of how people demonstrate themselves. There are significant gender distinctions in self-concepts. Scholars illustrated the selfconcepts could interpret gender differences in deeds, cognition, motivation, and emotion. Self-concepts are divided into individual self-concept, relational self-concept and collective self-concept [5]. Persons with Individual self-concept are driven by self- 
interests and a comparison of similarities and differences between themselves and others. Connections with particular others actuate workers with relational self-concept. Those with collective self-concept are motivated by community wellbeing and establishes self-definition based on meaningful team memberships. The individual selfconcept is congruent with "male" characteristics, while collective self-concept and relational selfconcept are related to communal features. Thereby, men tend to have individual self-concepts, while females tend to have relational selves and collective selves. Therefore, consistent with masculine characteristics, authoritarian leaders might are congruent with prototypical leaders among individuals with individual self-concepts. Instead, well-matched with female traits, benevolent leaders might be consistent with a prototype among people with relational self-concepts and collective selfconcepts.

Subordinates' results are including in-role (i.e., job performance) and extra-role (i.e. organizational citizenship behavior). Campbell et al. (1993) defined job performance as employees' behaviors covered in job descriptions to reach corporate targets [6]. Organizational citizenship behaviors (OCBs) are characterized as voluntary behaviors not involved in job descriptions yet are beneficial to the individuals or the organization (e.g., co-workers). Based on the goals, Williams \& Anderson (1991) divided OCB as OCB-I (i.e., Behaviors that help individuals) and OCB-O (i.e., behaviors that benefit the organization) [7].

In sum, the current research examines how selfconcepts of subordinates impact the association between leading styles and outcomes of subordinates.

\section{HYPOTHESIS}

Authoritarian leadership (which concentrates on results) may positively influence followers' job performance via their individual self-concept, which focuses on the comparison (including outcome's comparisons) with others. However, with individual self-concepts which are personal interest-focused and outcome-oriented, followers might be involved in less OCB-O and OCB-I.

Hypothesis 1: Via individual self-concept, authoritarian leadership is: (1a) positively related to subordinates' job performance; (1b) negatively related to subordinates' OCB-I ; (1c) negatively related to subordinates' OCB-O.

Research indicated that benevolent behaviors positively related to subordinates' performances, focusing on connections and concerns followers' well-being. Benevolent leadership may thus facilitate subordinate's relational self-concept as well as collective self-concept. In addition, both the subordinate's relational self-concept (i.e., emphasizing role relationship with particular others) and collective self-concept (i.e., revolving one's role within a group) concern others well-being and might positively be associated with organizational citizenship behaviors.

Hypothesis 2: Via subordinate's relational selfconcept, benevolent leadership is: (2a) positively related to subordinates' job performance; (2b) positively related to subordinates' OCB-I ; (2c) positive related to subordinates' OCB-O.

Hypothesis 3: Via subordinate's collective selfconcept, benevolent leadership is: (3a) positively related to subordinates' job performance; 3b) positively related to subordinates' OCB-I ; (3c) positive related to subordinates' OCB-O.

\section{METHODOLOGY}

Participants in the current study were 185 full-time workers who were recruited online. We collected 185 effective questionnaires. Among the respondents, there were 96 male subordinates (52\%), 89 female subordinates $(48 \%), 133$ male leaders $(72 \%)$, and 52 female leaders $(28 \%)$ from industries of IT, finance, etc.

Leadership styles (i.e. Authoritarian leadership and benevolent leadership) were tested by Cheng, et al., (2004) scale [8]. Subordinates self-concepts were measured by the Levels of Self-Concept Scale (Johnson, Lord \& Selenta, 2006) [9]. Job performance was measured by Williams and Anderson' (1991) Job Performance scale. [7]. OCBs (i.e., OCB-I, and OCB-O) were measured by Williams and Anderson's (1991) OCB scale [7]. Control variables were including the gender of leaders and subordinates; subordinates' age, industry, and education background.

\section{DATA ANALYSIS AND FINDINGS}

Internal consistency for the study variables was shown in Table 1. The correlations show that there are positive connections between individual selfconcept and authoritarian leadership $(\mathrm{r}=.25, \mathrm{p}<$ $.01)$, individual self-concept and job performance ( $\mathrm{r}$ $=.19, \mathrm{p}<.05)$, collective self-concept and benevolent leadership $(\mathrm{r}=.20, \mathrm{p}<.01)$, collective self-concept and job performance $(\mathrm{r}=.51, \mathrm{p}<.01)$, OCB-I $(\mathrm{r}=.35, \mathrm{p}<.01)$, OCB-O $(\mathrm{r}=.33, \mathrm{p}<.01)$. 
Table 1. Zero-Order Correlations and Alphas

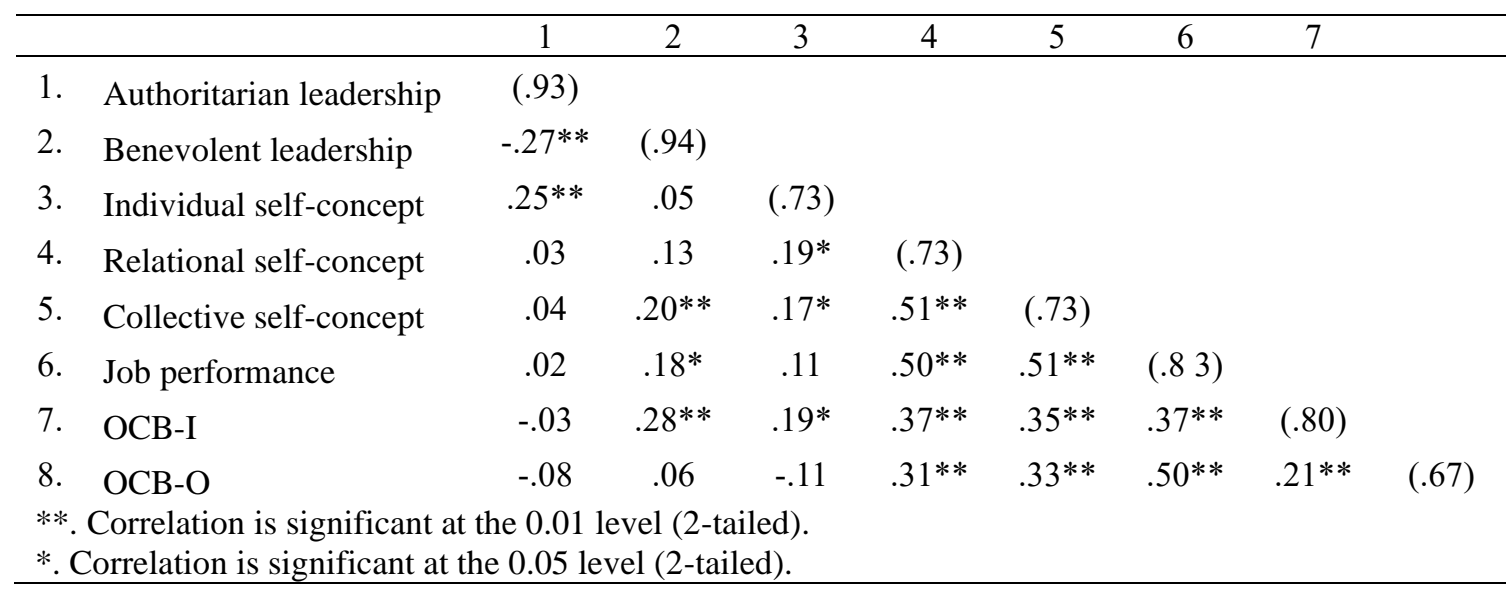

Hypotheses were tested using SPSS PROCESS (model 4). Our results are shown as follows:

Indirect effects of authoritarian leadership on job performance $(\beta=.02,95 \%$ CI $[.001, .043])$, OCB-I $(\beta=-.02,95 \%$ CI $[.005, .055])$ were all significant, supporting hypothesis $1 \mathrm{a}$ and $1 \mathrm{~b}$. There was no significant indirect effect of authoritarian leadership on OCB-O $(\beta=-.01,95 \%$ CI $[-.03, .01]$; see Table 2).

Indirect effects of benevolent leadership on job performance $(\beta=.03,95 \%$ CI $[.0003, .0766])$, OCBI $(\beta=.03,95 \%$ CI $[.0002, .0613])$ and OCB-O $(\beta=$
$.02,95 \%$ CI $[.001, .050])$ via relational self-concept were all significant, fully supporting hypothesis $2 \mathrm{a}$ and $2 \mathrm{c}$, and partially supporting hypothesis $2 \mathrm{~b}$ as the direct effect of benevolent leadership on OCB-I ( $\beta=$ $.15, \mathrm{p}<.001$ ) was significant (see Table 3 ).

Indirect effects of benevolent leadership on job performance $(\beta=.05,95 \%$ CI $[.02, .10])$, OCB-I $(\beta$ $=.03,95 \% \mathrm{CI}[.01, .07])$ and OCB-O $(\beta=.04$, $95 \%$ CI $[.01, .07])$ via collective self-concept were all significant. fully supporting hypothesis $3 \mathrm{a}$ and $3 \mathrm{c}$, and partially supporting $3 \mathrm{~b}$ as the direct effect of benevolent leadership on OCB-I $(\beta=.14, \mathrm{p}<.001)$ was significant (see Table 4).

Table 2. Results of Hypothesis 1 Testing

\begin{tabular}{|c|c|c|c|}
\hline \multirow{2}{*}{ Paths } & \multirow{2}{*}{$\boldsymbol{\beta}$} & \multicolumn{2}{|c|}{ CI } \\
\hline & & $\mathbf{L} \mathbf{L}$ & $\mathbf{U L}$ \\
\hline \multicolumn{4}{|l|}{ direct effect } \\
\hline authoritarian leadership --> job performance & .001 & -.08 & .08 \\
\hline authoritarian leadership --> OCB-I & -.05 & -.14 & .04 \\
\hline authoritarian leadership --> OCB-O & -.01 & -.09 & .07 \\
\hline \multicolumn{4}{|l|}{ indirect effect (via individual self-concept) } \\
\hline $\begin{array}{l}\text { 1a. authoritarian leadership --> individual self-concept --> job } \\
\text { performance }\end{array}$ & .02 & .001 & .043 \\
\hline $\begin{array}{l}\text { 1b. authoritarian leadership --> individual self-concept --> } \\
\text { OCB-I }\end{array}$ & .02 & .005 & .055 \\
\hline $\begin{array}{l}\text { 1c. authoritarian leadership --> individual self-concept --> } \\
\text { OCB-O }\end{array}$ & -.01 & -.03 & .01 \\
\hline
\end{tabular}


Table 3. Results of Hypothesis 2 Testing

\begin{tabular}{l|c|c|c}
\hline \multirow{2}{*}{ Paths } & $\boldsymbol{\beta}$ & \multicolumn{2}{c}{ CI } \\
\cline { 4 - 5 } & & & UL \\
\hline direct effect & .06 & -.02 & .14 \\
\hline benevolent leadership --> job performance & .15 & .08 & .23 \\
\hline benevolent leadership --> OCB-I & .002 & -.08 & .09 \\
\hline benevolent leadership --> OCB-O & & & \\
\hline indirect effect (via relational self-concept) & .03 & .0003 & .0766 \\
\hline $\begin{array}{l}\text { 2a. benevolent leadership --> relational self-concept --> job } \\
\text { performance }\end{array}$ & & .0002 & .0613 \\
\hline $\begin{array}{l}\text { 2b. benevolent leadership --> relational self-concept --> OCB- } \\
\text { I }\end{array}$ & .03 & .00 \\
\hline $\begin{array}{l}\text { 2c. benevolent leadership --> relational self-concept --> OCB- } \\
\text { O }\end{array}$ & .02 & .001 & .050
\end{tabular}

Table 4. Results of Hypothesis 3 Testing

\begin{tabular}{|c|c|c|c|}
\hline \multirow{2}{*}{ Paths } & \multirow{2}{*}{$\boldsymbol{\beta}$} & \multicolumn{2}{|c|}{ CI } \\
\hline & & $\mathbf{L L}$ & UL \\
\hline \multicolumn{4}{|l|}{ direct effect } \\
\hline benevolent leadership --> job performance & .04 & -.03 & .12 \\
\hline benevolent leadership --> OCB-I & .14 & .06 & .22 \\
\hline benevolent leadership --> OCB-O & -.01 & -.10 & .07 \\
\hline \multicolumn{4}{|l|}{ indirect effect (via relational self-concept) } \\
\hline $\begin{array}{l}\text { 3a. benevolent leadership --> collective self-concept --> job } \\
\text { performance }\end{array}$ & .05 & .02 & .10 \\
\hline $\begin{array}{l}\text { 3b. benevolent leadership --> collective self-concept --> } \\
\text { OCB-I }\end{array}$ & .03 & .01 & .07 \\
\hline $\begin{array}{l}\text { 3c. benevolent leadership }-->\text { collective self-concept }--> \\
\text { OCB-O }\end{array}$ & .04 & .01 & .07 \\
\hline
\end{tabular}

\section{CONCLUCION}

The current research's findings primarily supported the self-concepts' mediation effects. Firstly, results supported authoritarian leadership positively influences subordinates' job performance and negatively impacts their OCB-I via their individual self-concept. But individual self-concept does not affect the connection between authoritarian leadership style and OCB-O. Secondly, findings support that benevolent leadership positively predicts subordinates' job performance, OCB-I, OCB-O via their relational self-concept and collective self-concept.
These findings are partially consonant with the primary literature. Based on leadership social identity theory, the prototype among workers with individual self-concept possesses masculine characteristics. Followers tend to view managers with"masculine" leadership behaviors as in-group members. Therefore, a favorable assessment of the leadership was given by followers. Further, individual self-concept holders were interested in comparison with others. They consequently tend to concern about personal performance and compare welfare and salary with others. Thus, authoritarian leadership's positive evaluation gives rise to positive subordinates' job outcomes. The results of the connection between OCB and authoritarian leadership are congruent with the preceding 
evidence (i.e., authoritarian leadership negatively associates with OCB-I via individual self-concept).

In contrast, no significant effect of individual selfconcept was shown on the relationship between authoritarian leadership and OCB-O. Demanding managers are prone to push followers to try one's best towards more high-pitched performance. This controlling leadership may inhibit followers' motivation at work. Consequently, authoritarian leadership may demotivate followers to produce a surplus effort to work by increasing their tremendous outside burden. Another explanation is the focus of the followers. Authoritarian leadership highlight results. Followers with individual selfconcept focus on outcomes similarly. Therefore, followers with individual self-concepts tend to favour authoritarian leadership behaviors and focus on their work results and well-fair. They would be less likely to engage in OCBs without direct selfinterest.

Similarly, communal characteristics were shared by the prototype in a category of workers with collective self-concept and relational self-concept. Consequently, benevolent leaders tend to be regarded as group members. That is, in this situation, benevolent leadership would work better than authoritarian leadership. Because benevolent leadership focuses on individual connections, relational self-concept is assumed to be more positively associated with benevolent leadership than collective self-concept. Nevertheless, there are no significant discrepancies between the role of relational self-concept and collective self-concept on followers' job performance. Further studies should study the connection between benevolent leadership and self-concepts.

\section{REFERENCES}

[1] Farh, J. L., \& Cheng, B. S. (2000). A cultural analysis of paternalistic leadership in Chinese organizations. In J. T. Li, A. S. Tsui, \& E. Weldon (Eds.), Management and organizations in the Chinese context (pp. 94-127). London: Macmillan.

[2] Wang, A. C., Chiang, J. T. J., Tsai, C. Y., Lin, T. T., \& Cheng, B. S. (2013). Gender makes the difference: The moderating role of leader gender on the relationship between leadership styles and subordinate performance. Organizational Behavior and Human Decision Processes, 122(2), 101-113.

[3] Hogg, M. A., van Knippenberg, D., \& Rast, D. E. (2012). The social identity theory of leadership: Theoretical origins, research findings, and conceptual developments. European Review of Social Psychology, 23(1), 258-304.
[4] Hogg, M. A. \& Reid, S. A. (2006). Social Identity, Self-Categorization, and the Communication of Group Norms. Communication Theory, 16(1), 7-30.

[5] Brewer, M. B., \& Gardner, W. 1996. Who is this "we"? Levels of collective identity and self representations. Journal of Personality and Social Psychology, 71, 83-93.

[6] Campbell, J. P., McCloy, R. A., Oppler, S. H., \& Sager, C. E. (1993). A theory of performance. In N. Schmitt \& W. C. Borman (Eds.), Personnel selection in organizations (pp. 35-70). San Francisco, CA: Jossey-Bass.

[7] Williams, L. J., \& Anderson, S. E. (1991). Job satisfaction and organizational commitment as predictors of organizational citizenship and inrole behaviors. Journal of Management, 17, 601-617.

[8] Cheng, B. S., Chou, L. F., Wu, T. Y., Huang, M. P. \& Farh, J. L. (2004). Paternalistic leadership and subordinates responses: Establishing a leadership model in Chinese organizations. Asian Journal of Social Psychology, 7, 89-117.

[9] Johnson, R., Selenta, C., \& Lord, R. (2006). When organizational justice and the selfconcept meet: Consequences for the organization and its members. Organizational Behavior and Human Decision Processes, 99(2), 75-201. 